\title{
Construction of Illocutionary Speech Meaning: Analyses of Conversational Narratives of a Chinese 60-year-old Woman
}

\author{
Dongyi Zhu ${ }^{1}$ \\ ${ }^{1}$ Department of Foreign Languages and Literatures, Tsinghua University, Beijing, China \\ Correspondence: Dongyi Zhu, Department of Foreign Languages and Literatures, Tsinghua University, Haidian \\ District, Beijing, China. Tel: 86-134-8492-2064.
}

Received: October 31, 2015

Accepted: December 5, 2016

Online Published: December 13, 2016

doi:10.5430/elr.v5n4p54

URL: http://dx.doi.org/10.5430/elr.v5n4p54

\begin{abstract}
This case study centres to focus on 4 recording transcriptions as the main data from an outside-in perspective, to aim to analyze the different illocutionary forces expressed by a 60-year-old Chinese woman; thus, to seek whether there are any illocutionary differences between familiar people and strangers conveyed from her stories. Although some research has been done on Chinese speakers' categorization of speech acts, narrative and cognitive activities in conversational storytelling, and some have shown that for Chinese speakers, their utterance comprehension involves speech act recognition. However, concerning of the illocutionary acts in conversational narratives, the research is far from adequate. A complete pragmatic method of narrative could adopt both an outside-in approach to functions of narrative in context, looking at what we accomplish in telling stories and at what effects pragmatics have in speech events; and an inside-out approach, looking at how recurrent units function within narratives. The results showed that conversational stories were performed with the different kinds of illocutionary speech act functions not just to state or illustrate an affair or a point, but with illocutionary forces both direct and indirect in apologizing, requesting and rejecting, even indirect in declarations, which had gained opposite ideas from Norrick's (2015) claim in the denying of this function in conversational narratives. The study also showed that the leading narrator, the lady, employed identity construction in involving more direct illocutionary acts to familiar people than to strangers, and more indirect illocutionary acts in the entire narratives.
\end{abstract}

Keywords: Illocutionary speech act, Conversational narratives, Direct/indirect speech act, Outside-in approach

\section{Introduction}

The last decade has seen a vast research rise in studies on illocutionary speech acts in different languages and also in cross-linguistic or cross-cultural settings (see Holtgraves and Ashley, 2001; Kazuyoshi, 2009; Liu, 2011; Norrick, 2015). In line with this research trend, researchers have widely extended their fields in various pragmatic, discourse analytic and sociolinguistic studies. Although some research has been done on Chinese speakers' categorization of speech acts, narrative and cognitive activities in conversational storytelling (Liu, 2011; Zhao, 2015) have shown that for Chinese speakers, their utterance comprehension involves speech act recognition. However, concerning of the illocutionary acts in conversational narratives, the research is far from adequate. A complete pragmatic method of narrative could adopt both an outside-in approach to functions of narrative in context, looking at what we accomplish in telling stories and at what effects pragmatics have in speech events; and an inside-out approach, looking at how recurrent units function within narratives (Norrick, 2015). This case study, uses 4 recording transcriptions as the main data from an outside-in perspective, aiming to investigate the different illocutionary forces expressed by a 60-year-old woman and to seek whether there are any illocutionary differences between familiar people and strangers conveyed from her stories.

\section{Literature Review}

\subsection{Speech Act Theory}

A speech act in linguistics and the philosophy of language is an utterance that has a performative function in language and communication. According to Bach (1998, p.81), "almost any speech act is really the performance of several acts at once, distinguished by different aspects of the speaker's intention: there is the act of saying something, what one does in saying it, such as requesting or promising, and how one is trying to affect one's audience."

The review of the work on speech act theory can be dated back to Austin's distinguishing of the three layers of 
speech act: locutionary, illocutionary and perlocutionary (Austin, 1962). To Austin, speech acts should be considered "from the ground up how many senses there are in which to say something is to do something, or in saying something we do something and even by saying something we do something"(1962, p.94). This idea was the basis of his formulation of the above-mentioned three-fold distinction of speech act, i.e., the actual words that the speaker is saying refer to a locutionary act, the intention of the speaker refers to an illocutionary act, and the effect of the utterance on the hearer refers to a perlocutionary act. To describe such acts in a more sensitive way, Austin classified them into five groups (as shown in Table 1). However, Searle(1979, p.9) criticized Austin's taxonomy in several ways, including the criticism that Austin's classifications were not of speech acts but speech act verbs, not illocutionary acts but English illocutionary verbs, and that the taxonomy was not constructed on the basis of any clear or consistent principle or set of principles. It is quite puzzling to treat one utterance with different illocutionary acts, for instance,

(1) I'll be there tomorrow.

could be counted as

(a) a promise: I promise you that I'll be there tomorrow.

(b) a prediction: I predict that I'll be there tomorrow.

(c) or a warning: I warn you that I'll be there tomorrow.

and so on. So the same sentence can mean differently in different contexts. How can speakers be sure that the intended illocutionary force is recognized by the listener? Obviously, there is no communication without illocutionary force, specifically in a narrative context; how does the narrator convey, or narratee understand the illocutionary force of the story or narrative? The contextual conditions must be fulfilled before a speech act which can be properly performed. Thus Searle $(1979, \mathrm{p} .2)$ uses "felicity conditions" to explain such contextual conditions: illocutionary point (refers to an essential condition which is an instance of a culturally defined speech act type, and is characterized by a particular illocutionary force ); direction of fit ( refers to the preparatory condition between language and reality); expressed psychological state ( refers to the sincerity condition of the speaker's state of mind); and propositional content ( refers to the propositional content condition).

Due to the felicity condition and Searle's dissatisfaction with Austin's taxonomy, Searle listed his five groups of speech acts (1979, p.12-20) as comparisons to Austin's (1962, p.151) as shown in Table 1:

\begin{tabular}{|c|c|c|}
\hline & Austin's taxonomy & Searle's alternative taxonomy \\
\hline \multirow[t]{5}{*}{$\begin{array}{l}\text { Classifi- } \\
\text { cation }\end{array}$} & $\begin{array}{l}\text { Verdictives } \\
\text { (typified by the giving of a verdict) }\end{array}$ & $\begin{array}{l}\text { Assertives/Representatives (1975) } \\
\text { (to commit the speaker to the being of the case, } \\
\text { such as stating, reporting,etc.) }\end{array}$ \\
\hline & $\begin{array}{l}\text { Excercitives } \\
\text { (the exercising of powers, rights or } \\
\text { influence) }\end{array}$ & $\begin{array}{l}\text { Directives } \\
\text { (the attempts by the speaker to get the hearer to } \\
\text { do something, such as requesting, ordering, etc.) }\end{array}$ \\
\hline & $\begin{array}{l}\text { Commissives } \\
\text { (typified by promising or otherwise } \\
\text { undertaking) }\end{array}$ & $\begin{array}{l}\text { Commissives } \\
\text { (to commit the speaker to some future course of } \\
\text { action, on promising, offering, etc.) }\end{array}$ \\
\hline & $\begin{array}{l}\text { Expositives } \\
\text { (expository in how we are using } \\
\text { words) }\end{array}$ & $\begin{array}{l}\text { Expressives } \\
\text { (to express the psychological state about a state of } \\
\text { affairs, such like thanking, congratulating, } \\
\text { apologizing, etc.) }\end{array}$ \\
\hline & $\begin{array}{l}\text { Behabitives } \\
\text { (to do with attitudes and social } \\
\text { behavior) }\end{array}$ & $\begin{array}{l}\text { Declarations } \\
\text { (to bring about a change in reality, like } \\
\text { declaring, naming, etc.) }\end{array}$ \\
\hline
\end{tabular}

Searle's taxonomy further explains the fit of the words, or adapt to the world. This treatment of illocutionary acts has paved the way for researches in the latest decade with a vast research rise in studies of illocutionary speech acts in different languages and also in cross-linguistic or cross-cultural settings. Holtgraves and Ashley (2001) claimed that an utterance comprehension involves speech act recognition. Holtgraves (2005) experimentally examined the psychological reality of Searle's speech act classification scheme. Liu (2011) examines how Chinese speakers categorize speech acts and whether their utterance comprehension involves speech act recognition. Thus the 
linguistic inquiry regarding speech acts, especially the construction of illocutionary meaning, as an analytical tool (Kazuyoshi, 2009) to investigate cases in the Chinese naturally occurring conversational stories, is still a fresh sphere waited to be studied. For this research position itself at the juncture of these two fields, i.e. the construction of illocutionary meaning from conversational narratives.

\subsection{Conversational Narratives}

Before reviewing how conversational narratives express an illocutionary meaning, it is necessary to have a general scan of the development of narratives, especially of the concept and development of oral narratives and their update status in the Chinese context. The foremost beginning of this issue is of Labov and Walezky's (1967) study as "oral version of personal experience" on narrative analysis. In analyzing the 14 narratives from their collections, they Labov and Walezky (1967, p.21) gave a definition of a narrative as follows: "a narrative is a sequence of two or more narrative clauses, that is, a sequence of clauses separated by one or more temporal junctures", and more generally, a narrative acts as one method of recapitulating past experience by matching a verbal sequence of clauses to the sequence of events which actually occurred (Labov, 1972, 1982). Holding the same idea of "experience" like Labov, Richardson (1990, p.118) defines a narrative as the "primary way through which humans organize their experiences into temporally meaningful episodes; a narrative is both a mode of reasoning and a mode of representation". In other words, people can tell about their experience narratively and understand the world narratively.

To narratively tell one's experience in the form of stories, one should firstly pick up the story from his/her different kinds of past experiences. Schank (1990, p.29-40) has classified the sources, i.e. narrative stories, into five basic categories:

(1) Official stories (OS for short): These are stories we learn from official places such as school, church or the government.

(2) Invented (adapted) stories (IS): These are stories created by people. However, the process of the story creation and invention is one of adaptation rather than creation out of nothing.

(3) Firsthand stories (FS): People tell about their own experiences all the time. Firsthand experiential stories are the type of stories we talk about most. They represent our own personal experiences.

(4) Secondhand stories (SS): Secondhand experiential stories are simply the firsthand stories of others that we have heard and remembered. Telling secondhand experiences tends to be a much more straightforward process than telling firsthand stories, because the task is mostly an attempt at proper recall of the facts as they were heard.

(5) Culturally common stories (CS): The culturally common story is not as obvious as the other four. We get culturally common stories from our environment. No one person tells them, and no one person makes them up.

In this study, however, FS and SS in conversational narratives will be analyzed due to the fact that they are the type of stories we talk about most. Moreover, they are repeated with significant individual intentions and direct or indirect illocutionary meanings.

Conversational narratives have been widely researched in various pragmatic, discourse analytic and sociolinguistic studies (see Goodwin, 1997; Coates, 2001; Ochs and Capps, 2001; Schiffrin, 2001, Georgakopoulou, 2007; Zhao, 2015). Any transcription of everyday conversation is the transformation of locutionary vocal acts into literal sentences. The transcription is the only empirical resource for conversation analysis to reveal how the verbal actions of the participants are interrelated with each other at the locutionary level, such as turn-taking, adjacency pairs, preference structure and sequences, etc. Turn-taking is defined as "the projection of possible completion" (Sacks et al., 1974). Thus, any study of turn-taking cannot dispense with at least a minimum interpretation of the semantic content of an utterance which is relevant for illocutionary level (Kazuyoshi, 2009). Literary scholars have integrated aspects of speech act theory into narratology (Pratt, 1977; Kearns, 1999; Bernaert,2010). Tsiplakou and Floros (2013) concerns with the textual (illocutionary) forces such as instructing and entertaining for narrative texts like fables and jokes, but it goes on to consider both direct and indirect forces, illustrating from Searle(1975). Norrick (2015) takes an outside-in approach to study what speakers accomplish in telling stories in interaction. He believes that stories are not just to entertain or to illustrate a point.

Thus looking at what we can accomplish in telling stories and at what effects they have in speech events are the main aims of this study. Thus considering the overall force of conversational stories from Chinese speakers, a matter which received very limited and no systemic attention in the literature to date, has offered us new information for identifying conversational narratives as a way to fulfill speech act functions. 
The following questions are the particular concern of this research:

(1) What kinds of illocutionary speech acts do the conversational narratives count from the given data?

(2) How are the different illocutionary forces expressed by the 60-year-old woman and are there any illocutionary differences towards familiar people and strangers through her telling of the story?

\section{Research Design}

Participants. As from the title expressed, the present study mainly revolves around the naturally occurring conversational narratives between a 60-year-old woman and other people who lived in Beijing. The other people who participated in this data included the woman's 30-year-old son-in-law, a 45-year-old salesman in a clothing store, a middle-aged teacher from a university and myself as her daughter. The 60-year old woman was the leading person in generating various narratives.

Data. The data consist of four recordings lasting 75 minutes 30 seconds. The four examples are extracted from the woman's narratives in different settings; the university setting and the family setting. Which were recorded respectively in January 2014, and in September and October 2015. All the conversations were in Chinese.

Procedure. This paper performs a radio-based analysis. The analysis employs the corpus transcribed from the radio and draws from the analysis and rules of Conversation Analysis (CA). The fact that the participants felt comfortable and relaxed when talking with each other in different settings have facilitated data collection. The first conversation took place in a clothing store. It was about chatting and bargaining on the style and price of a coat, timing 24 minutes 56 seconds; The second conversation took place in a university lab between the woman and a female university teacher. The woman is talking about her story of reasons for being late to the lab (while she and her granddaughter had been invited by the teacher to do an experiment to her lab), timing 6 minutes 12 seconds. The third conversation was of a topic about a mother's acceptance of a new pair of shoes from her daughter, timing 27 minutes 55 seconds. And the last conversation was set by telephone; the woman was exchanging views and sharing happiness with her daughter-in-law about having babies; timing 16 minutes 27 seconds. The four conversational stories altogether lasted 75 minutes 30 seconds. All the conversations were in Chinese.

Data analyses. The recordings were firstly transcribed, double checked, and then analysed from an outside-in approach to make clear what speakers accomplish in telling stories in interaction. The conversational stories had overall forces in constructing illocutionary functions not only in stating and reporting an affair or a statement, but in performing directly and indirectly illocutionary forces like requesting, apologizing and others as well.

\section{Results and Discussion}

Norrick (2015) points out that for an adequate pragmatics of conversational narratives, we need an account of how stories match up with direct and indirect illocutionary acts, which acts stories typically perform and which acts they seldom perform or perhaps cannot perform. Stories initially function directly as representative speech acts like excuses and admissions rather than expressive speech acts like proper apologies : people admit what they did and how things happened in a narrative form, and they adopted a particular stance toward the events described, but often without directly expressing any emotional response, and often not addressed at the person who has suffered the injury or harm, and who would thus be the proper recipient of an apology, so that their stories are usually ending up as admissions and excuses.

As shown from the following four cases, different settings and stories were performed with the various kinds of illocutionary speech act which functions not just to state or illustrate an affair or a point, but with illocutionary forces both directly and indirectly in apologizing, requesting and rejecting, and even indirectly in declarations.

\subsection{M-B Narratives: Direct Representative but Indirect Directive Speech Act Function}

This story happens between M (the 60-year-old woman and short-written as M) and a clothing store boss (B for short), and it was in a clothing store that they have been chatting and bargaining on the style and price of a coat, when $\mathrm{M}$ recalls and tells her story to the boss in the hope of making a discount, a construction of the illocutionary speech meaning has been formed. Taking from an outside-in approach, the collected natural data will illustrate what people accomplish in telling stories and at what effects they have made in speech events. As Norrick's (2015) taking of an outside-in approach to conversational stories, we find M's story functioning not to just entertain or to illustrate a point, but with illocutionary forces like confessing and indicting, even apologizing and warning. But if taken for the different culturally defined Chinese conversational narratives, the stories seem to fulfill either direct or indirect illocutionary speech act, and sometimes, it is beaming with both direct and indirect speech meanings in a complete narrative. As the following example shows: 


\begin{tabular}{|c|c|c|}
\hline 23M: & $\begin{array}{l}\text { 啊呀: : } \\
\text { a ya:: }\end{array}$ & whoops:: \\
\hline 24 & $\begin{array}{l}\text { 这是我能接受的价格。 } \\
\text { zheshi wo neng jieshou de jiage. }\end{array}$ & that's the price I can accept. \\
\hline 25 & $\begin{array}{l}\text { 我之所以想买是因为我闺女喜欢它。 } \\
\text { wo zhisuoyi xiang mai shi yinwei wo guinv } \\
\text { xihuan ta. }\end{array}$ & $\begin{array}{l}\text { I want to buy it cause my daughter } \\
\text { likes it. }\end{array}$ \\
\hline 26 & $\begin{array}{l}\text { 便宜点吧。 } \\
\text { pianyi dian ba. }\end{array}$ & Cheaper, please. \\
\hline 27B: & $\begin{array}{l}\text { 你可以跟其他店里的衣服比比看看。 } \\
\text { ni keyi gen qita dianli de yifu bibi kankan. }\end{array}$ & $\begin{array}{l}\text { You can compare my goods } \\
\text { [with other stores. }\end{array}$ \\
\hline 28M: & $\begin{array}{l}\text { 就这吧, } \\
\text { jiuzhe ba. }\end{array}$ & [Come on, \\
\hline 29 & $\begin{array}{l}\text { 给你说实话吧, } \\
\text { gei ni shuo shihua ba, }\end{array}$ & let me tell you the truth, \\
\hline 30 & $\begin{array}{l}\text { 我家老头身体一直都病着, } \\
\text { wojia laotou shenti yizhi dou bingzhe, }\end{array}$ & my husband was not in good health:: \\
\hline 31 & $\begin{array}{l}\text { 他好几年前就退休了, 啥也没干, 一直在家 } \\
\text { 治病, } \\
\text { ta hao ji nian qian jiu tuixiu le, sha ye meigan, } \\
\text { yizhi zaijia zhibing, }\end{array}$ & $\begin{array}{l}\text { he retired several years ago and did } \\
\text { nothing except curing himself during } \\
\text { these years. }\end{array}$ \\
\hline 32 & $\begin{array}{l}\text { 我们厂也倒闭好多年了， } \\
\text { women chang ye daobi haoduo nian le, }\end{array}$ & $\begin{array}{l}\text { Our factory has also been closed } \\
\text { down for more than ten years, }\end{array}$ \\
\hline 33 & $\begin{array}{l}\text { 你看, } \\
\text { ni kan, }\end{array}$ & you see, \\
\hline 34 & $\begin{array}{l}\text { 我闺女还是个学生, } \\
\text { wo guinv hai shi ge xuesheng, }\end{array}$ & my daughter was still a student(.) \\
\hline 35 & $\begin{array}{l}\text { 我们真是不容易啊。 } \\
\text { Women zhenshi bu rongyi a }\end{array}$ & I don't live an easy life actually. \\
\hline 36 & $\begin{array}{l}\text { 但我真是想给我闺女把它买喽, } \\
\text { dan wo zhenshi xiang gei wo guinv bata maile, }\end{array}$ & $\begin{array}{l}\text { But I really want to buy this coat for } \\
\text { my daughter, }\end{array}$ \\
\hline 37 & $\begin{array}{l}\text { 所以给我便宜点行不行。 } \\
\text { suoyi geiwo pianyi dian xingbuxing. }\end{array}$ & so give me a discount please. \\
\hline 38B: & $\begin{array}{l}\text { 哦--, 好吧, } \\
\text { ao--, hao ba, }\end{array}$ & O---h, OK, \\
\hline 39 & $\begin{array}{l}\text { 看你真想买, } \\
\text { kan ni zhen xiang mai, }\end{array}$ & maybe you really want to take it. \\
\hline 40 & $\begin{array}{l}\text { 给你按 } 350, \\
\text { gei ni an } 350,\end{array}$ & I give you 350 \\
\hline 41 & $\begin{array}{l}\text { 算了, 就这吧 } \\
\text { suanle, jiuzhe ba }\end{array}$ & deal. \\
\hline
\end{tabular}

Consider this example of a story of past not-easy-life experience told in a context where it is exactly a request for a bargaining, is actually functioning as a direct representative and at the same time as an indirect directive. Before introducing her narrative, M had already stated her basic point in lines 24-25, it is for her daughter's favor that she wants to ask a discount from the store boss for a price which she can accept, and she returns to this bargain theme in lines 36-37, M is asking B to make a discount. Here we can return to Searle's (1969, p.66) treatment of request, that the sincerity condition is 'Speaker wants hearer to do some Action' and it 'counts as an attempt to get the hearer to do some Action'. M, however, is trying to make this bargain through telling her story to B, and (ends at line 37 ) to get B to give her the discount as a return. The attempt of $\mathrm{M}$ (line 37) is actually the sincerity condition of M's utterance if we can get a bird's-eye-view of the intention from her narrative. With all the contextual support, it is clear that a narrative with a direct representative function (M's statement of her past life experience) can assume the force of a request (M's attempt to get the discount from $B$ ), and thus of an indirect directive. 


\subsection{M-X Narratives: Indirect Expressive Speech Act Function}

The following story happens between $\mathrm{M}$ and a university teacher ( $\mathrm{X}$ for short). Apart from the two illocutionary acts cited in the first narrative case, the following sample story can be cited as functioning as an excuse for M's being late. $\mathrm{M}$ tells the story to explain why she was late when she met X.

\begin{tabular}{|c|c|c|}
\hline 1M: & $\begin{array}{l}\text { 啊呀让您久等了呀 } \\
\text { a-ya rang nin jiudeng le ya }\end{array}$ & $\begin{array}{l}\text { Oh, have you been waiting for a long } \\
\text { time.... }\end{array}$ \\
\hline 2 & $\begin{array}{l}\text { 夏老师, } \\
\text { Xialaoshi, }\end{array}$ & Mrs. Xia. \\
\hline 3X: & $\begin{array}{l}\text { 没关系,没关系， } \\
\text { meiguanxi meiguanxi, }\end{array}$ & That's OK, it's $\underline{\mathrm{OK}}$. \\
\hline 4 & $\begin{array}{l}\text { 路上难免出现什么情况嘛。 } \\
\text { lushang nanmian chuxian shenme qingkuang } \\
\text { ma. }\end{array}$ & $\begin{array}{l}\text { You can not avoid something } \\
\text { unexpected. }\end{array}$ \\
\hline 5 & $\begin{array}{l}\text { 没关系。 } \\
\text { meiguanxi. }\end{array}$ & It doesn't matter. \\
\hline $6 \mathrm{M}:$ & $\begin{array}{l}\text { 其实我们 } 7 \text { 点半就从家里出来, 一路小跑去 } \\
\text { 赶地铁, } \\
\text { qishi women } 7 \text { dian ban jiu cong jiali chulai, } \\
\text { yilu xiaopao qu gan ditie, }\end{array}$ & $\begin{array}{l}\text { We actually went out of home:: and } \\
\text { hurried to the subway station } 7 \text { at half } \\
\text { past seven, }\end{array}$ \\
\hline 7 & $\begin{array}{l}\text { 你知道不, } \\
\text { ni zhidao bu, }\end{array}$ & you know, \\
\hline 8 & $\begin{array}{l}\text { 但就是出西直门站的时候, } \\
\text { dan jiushi chu xizhimen zhan de shihou, }\end{array}$ & but when we get off at Xizhimen, \\
\hline 9 & $\begin{array}{l}\text { 我感觉不太舒服, } \\
\text { wo ganjue butai shufu, }\end{array}$ & I didn't feel well. \\
\hline 10 & $\begin{array}{l}\text { 我闺女让我休息一下, } \\
\text { wo guinv rangwo xiuxi yixia, }\end{array}$ & $\begin{array}{l}\text { My daughter suggested that I need a } \\
\text { rest, }\end{array}$ \\
\hline 11 & $\begin{array}{l}\text { 我就在地铁站的椅子上坐了快 } 20 \text { 分钟。 } \\
\text { wo jiu zai ditiezhan de yizi shang zuole kuai } 20 \\
\text { fenzhong. }\end{array}$ & $\begin{array}{l}\text { then we sat in the subway chair for } \\
\text { almost } 20 \text { minutes. }\end{array}$ \\
\hline 12 & $\begin{array}{l}\text { 就因为休息了一下，耽误了许多时间。 } \\
\text { jiu yinwei xiuxi le yixia, danwu le xuduo } \\
\text { shijian. }\end{array}$ & $\begin{array}{l}\text { It is for this rest that we have wasted } \\
\text { much time(.) }\end{array}$ \\
\hline 13 & $\begin{array}{l}\text { 哎, } \\
\text { ai, }\end{array}$ & Well, \\
\hline 14 & $\begin{array}{l}\text { 这就是常说的，起了个大早赶了个晚集。 } \\
\text { zhe jiushi changshuo de ,qile ge dazao ganle ge } \\
\text { wanji. }\end{array}$ & $\begin{array}{l}\text { it's the very example who set up early } \\
\text { but to catch a late. }\end{array}$ \\
\hline 15 & $\begin{array}{l}\text { 幸好, } \\
\text { xinghao, }\end{array}$ & Fortunately, \\
\hline 16 & $\begin{array}{l}\text { 宝宝一直状态挺好的, } \\
\text { baobao yizhi zhuangtai tinghao de, }\end{array}$ & the baby behaves well all the way, \\
\hline 17 & $\begin{array}{l}\text { 希望她一会进了录音室能好好表现。 } \\
\text { xiwang ta yihui jinle luyinshi neng haohao } \\
\text { biaoxian. }\end{array}$ & $\begin{array}{l}\text { hope she can have }[\text { a good } \\
\text { performance in the lab later. }\end{array}$ \\
\hline 18X: & $\begin{array}{l}\text { 好的, } \\
\text { haode, }\end{array}$ & [That's good. \\
\hline 19 & $\begin{array}{l}\text { 哎呦, } \\
\text { aiyou, }\end{array}$ & Come on, $\mathrm{OH}$, \\
\hline 20 & $\begin{array}{l}\text { 小宝宝好可爱啊！ } \\
\text { xiao baobao hao keai a! }\end{array}$ & how cute is the baby! \\
\hline
\end{tabular}


This little story does not count as a direct apology in speech act terms, since $\mathrm{M}$ only describes the circumstances surrounding her at the time of her uncomfortable situation of her heart. $\mathrm{M}$ is just telling the story (lines 6-14) to $\mathrm{X}$ without expressing regret, she justifies her behavior but does not articulate her feelings about being late for the lab. In Searle's (1969) consideration of illocutionary acts, apologizing qualifies as an expressive act with a sincerity condition such as 'the speaker feels sorry about the past act', and an essential condition that the speech act expresses this feeling;this view can also be found form Bach and Harnish's (1979, p.51) treatment of illocutionary acts. This kind of expression belongs to acknowledgements, which is one of the four main kinds of communicative illocutionary acts. Thus apologizing 'expresses regret for having harmed or bothered the hearer'. However, M's story does not say anything explicit about her feelings. $M$ is just seeking to minimize her being late by saying from the outset of the story "actually" in line 6 , and to further explain the real situation in line 7 and 8 with discourse markers as "you know" and "but". The following extended story is a plain description of events happening on her way to X's lab. $\mathrm{M}$ in line 14 states that "the very example" to show the unexpected situation which she believes that an apology is unnecessary. M's story certainly counts as an indirect apology in addressing her felicity conditions in the sense of Searle (1975): that is, the essential or sincerity conditions for the successful and felicitous performance of an illocutionary act, in the case of an apology, for instance, saying one admits responsibility for or feels bad about an injury to the addressee.

It is by an excuse that $\mathrm{M}$ wants $\mathrm{X}$ to understand her being late to the lab, even if X says "it's OK", $M$ seemingly excuses herself from this story to avoid the responsibility which $\mathrm{X}$ might point out, but actually not even with one apologizing word.

\subsection{M-D Narratives: Direct Representative but Indirect Expressive Speech Act Function}

The following example is of a story told as a statement within the topic where mother and daughter are giving their own reasons for the acceptance of a new pair of shoes. M's daughter (D for short) wants to show her caring respect to her mother by buying a new pair of shoes for her mom, but the mom takes it as a waste of money as she herself has a lot of shoes at home. When the narrative turns to focus on the mother's recall of two of her favorite shoes, she is obviously stating her disinterest in new things, and seemingly a rejection of the new shoes offered by her daughter. 


\begin{tabular}{|c|c|c|}
\hline 3D: & $\begin{array}{l}\text { 我给你买了一双加棉的名牌鞋(.) } \\
\text { wo gei ni maile yishuang jiamian de mingpai } \\
\text { xie(.) }\end{array}$ & $\begin{array}{l}\text { I've bought you a pair of } \\
\text { famous-brand cotton shoes(.) }\end{array}$ \\
\hline 4 & $\begin{array}{l}\text { 没有买你看中的那双过时的便宜鞋, } \\
\text { meiyou mai ni kanzhong de nashuang guoshi de } \\
\text { pianyi xie, }\end{array}$ & $\begin{array}{l}\text { instead of that cheaper and unstylish } \\
\text { one which you prefer. }\end{array}$ \\
\hline 5M: & $\begin{array}{l}\text { 你真是... } \\
\text { ni zhen shi... }\end{array}$ & You are really....... \\
\hline 6 & $\begin{array}{l}\text { 我给你说了那双便宜的就行, } \\
\text { wo gei ni shuole nashuang pianyi de jiuxing, }\end{array}$ & $\begin{array}{l}\text { I have told you the cheaper pairs will } \\
\text { be OK, }\end{array}$ \\
\hline 7 & $\begin{array}{l}\text { 你又不是不知道, } \\
\text { ni youbushi bu zhidao, }\end{array}$ & and you know, \\
\hline 8 & $\begin{array}{l}\text { 我家里已经有那么多双鞋子了, } \\
\text { wo jiali yijing you name duo shuang xiezi le, }\end{array}$ & $\begin{array}{l}\text { I have SO many shoes to wear at } \\
\text { home, }\end{array}$ \\
\hline 9 & $\begin{array}{l}\text { 有你爸前几年给我买的这双, } \\
\text { you niba qian ji nian gei wo mai de zhe shuang, }\end{array}$ & $\begin{array}{l}\text { the one your father bought me several } \\
\text { years before, }\end{array}$ \\
\hline 10 & $\begin{array}{l}\text { 还有在上海买的这双, } \\
\text { haiyou zai Shanghai mai de zhe shuang, }\end{array}$ & and the one I bought in Shanghai, \\
\hline 11 & $\begin{array}{l}\text { 你还记得那年么? } \\
\text { ni hai jide na nian me? }\end{array}$ & Do you still remember that year? \\
\hline 12 & $\begin{array}{l}\text { 上海世博会? } \\
\text { Shanghai shibohui? }\end{array}$ & [The Shanghai World Expo? \\
\hline 13D: & $\begin{array}{l}\text { 记得, 我是世博会志愿者。 } \\
\text { jide, wo shi shibohui zhiyuanzhe. }\end{array}$ & [Yes. I was the Expo volunteer. \\
\hline 14M: & $\begin{array}{l}\text { 恩...我去世博会看你后, } \\
\text { en...wo qu shibohui kanni hou, }\end{array}$ & $\begin{array}{l}\text { En... After I went to see you at the } \\
\text { Expo, }\end{array}$ \\
\hline 15 & $\begin{array}{l}\text { 在南京路买了一双鞋。 } \\
\text { zai Nanjing lu mai le yishuang xie. }\end{array}$ & $\begin{array}{l}\text { I bought a pair of shoes in Nanjing } \\
\text { Road. }\end{array}$ \\
\hline 16 & $\begin{array}{l}\text { 那个商场正在打折季。 } \\
\text { nage shangchang zhengzai dazheji. }\end{array}$ & That mall was at its sales season. \\
\hline 17 & $\begin{array}{l}\text { 我可喜欢那双鞋, } \\
\text { wo ke xihuan nashuang xie, }\end{array}$ & Wow, I really like that pair of shoes, \\
\hline 18 & $\begin{array}{l}\text { 我不是给你说过，我可喜欢那双鞋了， } \\
\text { wo bushi geini shuoguo, wo ke xihuan nashuang } \\
\text { xie le, }\end{array}$ & $\begin{array}{l}\text { I'm telling you that these two shoes } \\
\text { are my favorite, }\end{array}$ \\
\hline 19 & $\begin{array}{l}\text { 就是我忘了把它带过来。 } \\
\text { jiushi wo wang le ba ta daiguolai. }\end{array}$ & but I just forgot to bring them here. \\
\hline 20 & $\begin{array}{l}\text { 你看... } \\
\text { ni kan... }\end{array}$ & you know... \\
\hline 21 & $\begin{array}{l}\text { 买一双便宜鞋就行了, } \\
\text { mai yishuang pianyi xie jiu xingle, }\end{array}$ & to buy a cheaper one is $\mathrm{OK}$, \\
\hline 22 & $\begin{array}{l}\text { 就是用来下雪天穿。 } \\
\text { jiushi yonglai xiaxue tian chuan. }\end{array}$ & it is only worn in snowy days. \\
\hline
\end{tabular}

The turn states in lines 7-8, where M admits having many shoes at home. The story continues in line 9, where $\mathrm{M}$ is recalling her favorite shoes to explain that it is unnecessary to buy her new shoes. The story works not only as a statement of M's current need for shoes, but also as a reject for her thinking as "waste of money" behavior of her daughter. Still, stating is a specific type of representative speech act, while rejection belongs to an indirect expressive act. For this indirect speech act there must be an inference from the direct force to another type of illocutionary act 
distinct from representative act. Here rejection performs this indirect force. $M$ tries to embed her story in her statement so as not to go far from her rejection, then lines 17-18 explain her rejection and lines 19-22 further expound her statement as a whole. The interesting thing is that a rejection is also interpreted by Kent and Harnish as a kind of acknowledgments (1979, p.53), in that the speaker rejects the hearer's acknowledgment for the speaker's utterance is "lack of appreciation to the hearer's acknowledgment", and perhaps also is "the intention that the hearer takes the speaker's utterance as violating this expectation".

\subsection{M-J Narratives: Direct Representative but Indirect Declarations and again Indirect Directive Speech Act Function}

So we have seen that narratives have taken types from representative speech act to indirect-oriented expressive and directive acts. The following extract taken from the exchanges between $\mathrm{M}$ and her son-in-law (J) will give us new insights. They are sharing the happiness about having babies but talking occasionally about the responsibility of becoming a father, or, a parent. M's story is treated as an encouragement to her son-in-law. And if considered from the speech act terms, it can be counted not only as a direct representative, but also as an indirect declarations, and an indirect directive (a request).

\begin{tabular}{|c|c|c|}
\hline $1 \mathrm{~J}:$ & $\begin{array}{l}\text { 真是太遗憾了, Etta 出生时我没有在医院。 } \\
\text { zhenshi taiyihan le, Etta chusheng shi wo meiyou zai } \\
\text { yiyuan. }\end{array}$ & $\begin{array}{l}\text { It's really a pity that I wasn't in the hospital when } \\
\text { Etta was born. }\end{array}$ \\
\hline 2M: & $\begin{array}{l}\text { 你又不能预测小孩啥时候出生。 } \\
\text { ni you buneng yuce xiaohai sha shihou chusheng. }\end{array}$ & $\begin{array}{l}\text { You can never predict what will happen to a } \\
\text { coming baby. }\end{array}$ \\
\hline 3 & $\begin{array}{l}\text { 你不知道, 我生 D 的时候 } \\
\text { ni bu zhidao, wo sheng D de shihou, }\end{array}$ & Do you know when I was giving birth to D, \\
\hline 4 & $\begin{array}{l}\text { 也是这样... } \\
\text { yeshi zheyang... }\end{array}$ & it's almost the same scene... \\
\hline 5 & $\begin{array}{l}\text { 我还记得那天我跟你姨一起去赶集, } \\
\text { wo hai jide natian wo gen ni yi yiqi qu ganji, }\end{array}$ & $\begin{array}{l}\text { I still remember I went to the the market with your } \\
\text { aunt that day, }\end{array}$ \\
\hline 6 & $\begin{array}{l}\text { 谁能想到 D 那天就出来了呢。 } \\
\text { shui neng xiangdao D na tian jiu chulai le ne. }\end{array}$ & $\begin{array}{l}\text { but nobody could imagine that } \mathrm{D} \text { was coming on } \\
\text { that day. }\end{array}$ \\
\hline 7 & $\begin{array}{l}\text { 你爸也没能陪我去医院, } \\
\text { ni ba ye mei neng pei wo qu yiyuan, }\end{array}$ & Your father did not come with me to the hospital, \\
\hline 8 & $\begin{array}{l}\text { 也没能听见 D 的第一声哭。 } \\
\text { ye meineng tingjian D de diyisheng ku. }\end{array}$ & nor did he hear the first cry of D. \\
\hline 9 & $\begin{array}{l}\text { 那你看, } \\
\text { na ni kan, }\end{array}$ & But you see, \\
\hline 10 & $\begin{array}{l}\text { 他不是还是可爱她? } \\
\text { ta bushi haishi ke ai ta? }\end{array}$ & he loves D so much, [huh? \\
\hline 11J: & $\begin{array}{l}\text { 是啊, 那是肯定了。 } \\
\text { shi a, na shi kending le. }\end{array}$ & [yeah, of course. \\
\hline 12M: & $(0.4)$ & $(0.4)$ \\
\hline 13 & $\begin{array}{l}\text { 我给你说, } \mathrm{J}(.) \\
\text { wo gei ni shuo, } \mathrm{J}(.)\end{array}$ & I'm telling you, J(.) \\
\hline 14 & $\begin{array}{l}\text { 不管你那时候在不在场, } \\
\text { buguan ni nashihou zaibuzai chang, }\end{array}$ & no matter what you are doing at that special time, \\
\hline 15 & $\begin{array}{l}\text { 你现在都是一个爸爸了。 } \\
\text { ni xianzai dou shi yige baba le. }\end{array}$ & you are a father now. \\
\hline 16 & $\begin{array}{l}\text { 你人生进入新阶段了, } \\
\text { ni rensheng jinru le xin jieduan le, }\end{array}$ & you are in a different level now, \\
\hline 17 & $\begin{array}{l}\text { 既然都已经是当爹的人了, } \\
\text { jiran dou yijing shi dang die de ren le, }\end{array}$ & I mean you have become a father now. \\
\hline 18 & $\begin{array}{l}\text { 你就应该承担更多的责任, 更加努力的工作。 } \\
\text { ni jiu yinggai chengdan gengduo de zeren, gengiia } \\
\text { nuli de gongzuo. }\end{array}$ & You should be more responsible and work harder. \\
\hline
\end{tabular}


It is clear that while $\mathrm{J}$ is showing his pity in the absence of the birth of his daughter, $\mathrm{M}$ is trying to convince him of her past story (lines 3-8) in order to give him more encouragement, and by announcing him "become a father now" (line 17), M's narratives can be understood as a reminder of responsibility to $\mathrm{J}$, for which she hope to share the sense of obligation with J. As Searle (1969, p.18) clarified: the speaker and hearer must occupy special places within an extra-linguistic institution. M's identity as J's mother-in-law is rendering an authoritative status role to J. Declarations, too, bring about states of affairs to come and they generally prescribe particular wording to set some institutionalized act in motion, and it is a rhetorical support to show an elder's pronouncement in this narrative example. "I mean you become..." in line 17 is actually a declaration with an elder identity performing activity, and in announcing the truth of J's being "a father", to give her wanting of J to "work more hard" in the future (in line 18). If it was taken from the preparatory condition of this narrative, the last line has obviously shown what Searle's considerations of "Hearer is able to do the Act, and the Speaker believes the Hearer is able to do the Act", which accordingly performs an indirect directive force, i.e., a request.

We have seen that the four conversational stories have respectively performed different kinds of illocutionary forces. But as discussed by Searle(2001, p.70) himself, because there are several different dimensions of illocutionary forces, and because the same utterance act may be performed with a variety of different intentions, it is important to realize that one and the same utterance may constitute the performance of several different illocutionary acts, such as in M-B, M-D and M-J narratives. It is rarely seen that the same story is told just to be a story. M then in those settings has tried her utmost to show her intention through the story, and listeners, from the above analysis, have all returned response to acts such as lowering the price of B; and accepting M's reason in unwanting for the shoes from D, and more encouragement and sense of responsibility from $\mathrm{J}$. Then, for identity construction, $\mathrm{M}$ has involved more direct illocutionary acts to relatives (as to D and J) than to strangers (as to B and X); and more indirect illocutionary acts, from which the four cases have all realized indirect illocutionary forces, than direct ones in the entire narratives.

Here one thing should also be noticed is that the first person narratives have worked entirely as representatives for the statement and description to the listeners, it involves positioning, alignment and stance-taking on the part of the teller with consequences for identity construction. These four firsthand stories from $\mathrm{M}$, which are all her past personal experiences, are repleted with significant individual intentions and functioned with either direct or indirect illocutionary meanings in her telling.

\section{Conclusion}

In this outside-in approach to narratives from the 60-year-old woman's conversations with four different people, the construction of the overall direct and indirect illocutionary speech meanings was explored. The findings are:

(1) The four narrative cases have generally realized directly the force of representative acts such as stating an affair and making excuses, even they indirectly perform such directive acts as requesting and such expressive acts as apologizing and rejecting, and also declarations as announcing.

(2) Conversational stories are performed with different kinds of illocutionary speech act functions not just to state or illustrate an affair or a point, but also with illocutionary forces both directly and indirectly in apologizing, requesting and rejecting, even indirectly in declarations, which has gained opposite ideas from Norrick's (2015) claim in the denying of this function in conversational stories. Yet this case study does not find the instance story in functioning as commissives, which are directed toward to future action, whereby narratives are mostly concerned with past experiences and events. Another thing which should be noticed is that M's narrations have worked entirely as representatives for the statement and description to the listeners, they involved positioning, alignment and stance-taking on the part of $\mathrm{M}$, the story teller, with consequences for identity construction in involving more direct illocutionary acts to relatives than to strangers, and more indirect illocutionary acts than direct in the entire narratives.

In addition, due to various constraints, the participants of this case study were limited in terms of the number in participating to M's narratives and their familiarity with $\mathrm{M}$, which could exert impacts on the generalizibity of the construction of illocutionary speech meanings. Obviously more data from various ranges of contexts and by different people would better reflect the issues in the construction of illocutionary meanings through Chinese conversational narratives.

\section{References}

Austin,J.L. (1962). How to do things with words. Harvard.

Bach,K. (1998). Speech Acts. In E. Craig (Ed.), Routledge encyclopedia of philosophy, 9, 81-87. London and New York: Routledge. 
Bach,K. \& Harnish, R.M.(1979). Linguistic communication and speech acts. Cambridge, Mass: MIT Press.

Bernaerts, L. (2010). Interactions in Cuckoo's Nest: elements of a narrative speech-act analysis. Narrative ,18, 276-299. https://doi.org/10.1353/nar.2010.0004

Coates, J. (2001). My mind is with you: story sequence in the talk of male friends. Narrative Inquiry, 11(1), 81-101. https://doi.org/10.1075/ni.11.1.04coa

Georgakopoulou,A. (2007). Small stories, interaction and identities. Amsterdam/Philadelphia: John Benjamins. https://doi.org/10.1075/sin.8

Goodwin,M.(1997). By-Play:negotiating evaluation in story-telling. In G. Guy, J. Baugh, D. Schiffrin, \& C. Feagin, (Eds.), Towards a social science of language: Papers in honor of William Labov (pp.77-102). Philadelphia: John Benjamins. https://doi.org/10.1075/cilt.128.08goo

Holtgraves, T. \& Ashley, A. (2001). Comprehending illocutionary force. Memory \& Cognition,29,83-90. https://doi.org/10.3758/BF03195743

Kazuyoshi, S. (2009). Speech acts, moves, and meta-communication in negotiation: three cases of everyday conversation observed among the Gui former-foragers. Journal of Pragmatics, 41, 93-135. https://doi.org/10.1016/j.pragma.2008.09.006

Kearns, M. (1999). Rhetorical narratology. Lincoln: University of Nebraska Press.

Labov, W. (1972). Language in the inner city. Philadelphia: University of Pennsylvania.

Labov, W. (1982). Speech actions and reactions in personal narrative. In D. Tannen (Ed.), Analyzing discourse: Text and talk (pp.219-247). Washington DC: Georgetown University Press.

Labov, W. \& J. Waletzky. (1967). Narrative analysis: Oral versions of personal experience. In J. Helm (Ed.), Essays on the Verbal and Visual Arts: Proceedings of the 1966 Annual Spring Meeting of the American Ethnological Society (pp.12-44). Seattle: University of Washington Press.

Liu, S. (2011). An experimental study of the classification and recognition of Chinese speech acts. Journal of Pragmatics, 43, 1801-1817. https://doi.org/10.1016/j.pragma.2010.10.031

Norrick, N.R. (2015). Narrative illocutionary acts direct and indirect. Journal of Pragmatics, 86, 94-99. https://doi.org/10.1016/j.pragma.2015.05.008

Ochs,E. \& Capps,L. (2001). Living narrative. Creating lives in everyday storytelling. Cambridge/London: Harvard University Press.

Pratt, M.L. (1977). Toward a speech act theory of literary discourse. Bloomington: Indiana University Press.

Richardson,L. (1990). Narrative and sociology. Journal of Contemporary Ethnography, 19, 116-135. https://doi.org/10.1177/089124190019001006

Sacks,H., Schegloff, E. A., Jefferson, G. (1974). A simplest systematic for the organization of turn-taking system for communication. Language, 50, 696-735. https://doi.org/10.1353/lan.1974.0010

Schank, R.C. (1990). Tell me a story: Narrative and intelligence. Evanston, Illinois: Northwestern University Press.

Schiffrin,D. (2001). In other words: Variation in reference and narrative. Cambridge: Cambridge University Press.

Searle, J.R. (1969). Speech acts: An essay in the philosophy of language. Cambridge: Cambridge University Press. https://doi.org/10.1017/CBO9781139173438

Searle, J.R. (1975). Indirect speech acts. In P. Cole and J.L. Morgan (Eds.), Syntax and semantics: Speech acts (pp.59-82). New York: Academic Press.

Searle, J.R. (1979). Expression and meaning. Cambridge: Cambridge University Press. https://doi.org/10.1017/CBO9780511609213

Searle,J.R. (1989). How Performatives Work. Linguistics and Philosophy, 12, 535-558. https://doi.org/10.1007/BF00627773

Zhao, Y. (2015). A three dimensional social practice-oriented perspective of spontaneous conversational narrative. Beijing: China Social Sciences Press. 